\title{
Sistem Informasi Geografis Lokasi TKA-TPA Dibawah Naungan Badko Kabupaten Bantul Berbasis Foto Geotag
}

\author{
Apriliya Kurnianti1*, Revano Akbar Rizki², dan Laila Ma'rifatul Azizah ${ }^{3}$ \\ 1. Teknologi Informasi, Fakultas Teknik, Universitas Muhammadiyah Yogyakarta, I. Brawijaya, Geblagan, Tamantirto, Kec. Kasihan, \\ Yogyakarta, Daerah Istimewa Yogyakarta 55183 \\ Email:aprilia@ft.umy.ac.id \\ DOI: $10.18196 / p p m .32 .206$
}

\begin{abstract}
Abstrak
Di Kecamatan Bantul terdapat sekitar 40-an unit Taman Kanak-Kanak Alquran - Taman Pendidikan Alquran (TKA-TPA) yang berada di bawah naungan Badan Koordinasi (Badko). Saat ini, pengelolaan data TKA-TPA oleh Badko masih dilakukan secara konvensional. Badko Bantul mengalami beberapa masalah dalam proses pengambilan data, di antaranya hambatan dalam pengambilan data, yaitu akses informasi mengenai pendataan yang sering terlambat, lamanya proses pendataan dan pengolahan, dan belum adanya sistem informasi terpusat tentang lokasi TKA-TPA yang ada di Kabupaten Bantul. Pembuatan "Sistem Informasi Geografis Lokasi TKA - TPA di Bawah Naungan Badko Kabupaten Bantul Berbasis Foto Geotag" bertujuan untuk menyediakan informasi berupa laporan data unit, laporan data akreditasi unit, laporan data ustaz, laporan data santri, dan laporan data ketersediaan ustaz dalam satu unit TPA. Metode yang digunakan dalam pengembangan sistem adalah model prototyping. Model prototyping merupakan salah satu metode siklus hidup sistem yang didasarkan pada konsep model bekerja (working model) yang pembuatan sistemnya diawali dengan melakukan analisis lingkungan internal, mengidentifikasi kebutuhan sistem informasi, dan memberikan usulan sistem informasi yang akan dibuat berdasarkan hasil analisis. Hasil akhir berupa sistem informasi yang digunakan untuk mengoordiniasi, membina, dan meningkatkan kualitas pengelolaan TKA-TPA di Kabupaten Bantul yang berbasis foto geotag. Kesimpulannya adalah sistem informasi sudah dapat berjalan dan diimplementasikan dengan baik.
\end{abstract}

Kata Kunci: Badko Bantul, Foto Geotag, Sistem Informasi

\section{Pendahuluan}

Badko TKA-TPA Kabupaten Bantul merupakan wahana koordinasi pembinaan, komunikasi dan kerja sama TKA-TPA se-Provinsi Daerah Istimewa Yogyakarta. Badko TKATPA Kabupaten Bantul mempunyai visi menyongsong masa depan Islam yang gemilang dengan menyebarluaskan kesejukan Alquran. Adapun tujuan Badan Koordinasi TKA-TPA Kabupaten Bantul adalah mengoordinasi, membina, dan meningkatkan kualitas pengelolaan TKA-TPA di Kabupaten Bantul.

Perkembangan TKA-TPA di Kabupaten Bantul di satu sisi sangat menggembirakan, tetapi di sisi lain realita di lapangan menunjukkan bahwa kualitas pengelolaan TKA-TPA di Kabupaten Bantul perlu ditingkatkan dan dievaluasi. Kualitas pengelolaan TKA-TPA di Kabupaten Bantul beragam. Ada yang mutunya dapat di banggakan, tetapi tidak sedikit yang berada di bawah standar mutu. Untuk meningkatkan kualitas TKA-TPA, perlu dilakukan kegiatan supervisi. Supervisi merupakan keseluruhan usaha yang bersifat pembinaan bagi seluruh proses pengelolaan TKA-TPA untuk mengembangkan situasi dan kondisi Kegiatan Belajar Mengajar (KBM) yang lebih baik . Data-data tersebut dikelola oleh Bidang Penelitian dan Pengembangan (LITBANG) Data untuk selanjutnya dilakukan tindakan.

Dalam realita di lapangan saat ini, pengelolaan TKA-TPA yang dilakukan secara konvensional memerlukan evaluasi untuk meningkatkan pengelolaannya. Beberapa masalah yang ada di lapangan adalah dalam proses pengambilan data. Saat pengurus Badko TKA-TPA akan mengambil data, mereka sering mengalami hambatan, seperti akses informasi mengenai pendataan yang sering terlambat, lamanya proses pendataan dan pengolahan karena masih 
dilakukan secara manual, dan belum adanya sistem informasi terpusat tentang lokasi TKA-TPA yang ada di Kabupaten Bantul.

Berdasarkan penjabaran tersebut, tujuan dilakukannya pengabdian masyarakat ini adalah untuk membantu Badko TKA-TPA Kabupaten Bantul mencapai visi dan misinya dengan cara membuat sebuah sistem informasi yang sesuai dengan kondisi organisasi. Untuk itu, solusi yang ditawarkan adalah pembuatan sistem informasi geografis lokasi Taman Kanak-kanak Alquran dan Taman Pendidikan Alquran di bawah naungan Badko TKA-TPA Kabupaten Bantul berbasis foto geotag.

Geo-tagging bisa juga disebut geo-tag. Geo-tagging menghubungkan lokasi geografis dengan item, seperti foto (Jejaring, 2008). UML (Unified Modelling Language) adalah salah satu alat bantu yang sangat handal di dunia pengembangan sistem yang berorientasi objek. Hal ini disebabkan UML menyediakan bahasa pemodelan visual yang memungkinkan bagi pengembang sistem untuk membuat cetak biru atas visi mereka dalam bentuk yang baku, mudah dimengerti, dan dilengkapi dengan mekanisme yang efektif untuk berbagi dan mengomunikasikan rancangan mereka pada yang lain (Munawar, 2005). Pada pengembangan sistem informasi berbasis foto geotag ini, mitra pengabdian merupakan seorang expert user. Expert user (dedicated user) adalah pengguna komputer yang berpengalaman yang banyak menghabiskan waktunya untuk menggunakan program aplikasi khusus (IMK10Desain_User_Interface.pdf, 2020).

\section{Metode Pelaksanaan}

Metode pengembangan sistem informasi dibuat menggunakan metode prototyping. Dalam metode prototyping, perangkat lunak yang dihasilkan dipresentikan kepada user. User kemudian diberi kesempatan untuk memberikan masukan dan kritikan sehingga software yang dihasilkan sesuai dengan kebutuhan dan keinginan user. Perubahan perangkat lunak dapat dilakukan berkali-kali hingga dicapai kesepakatan bentuk dari software yang akan dikembangkan. Tahapan dalam pengembangan dapat dilihat pada gambar 1.

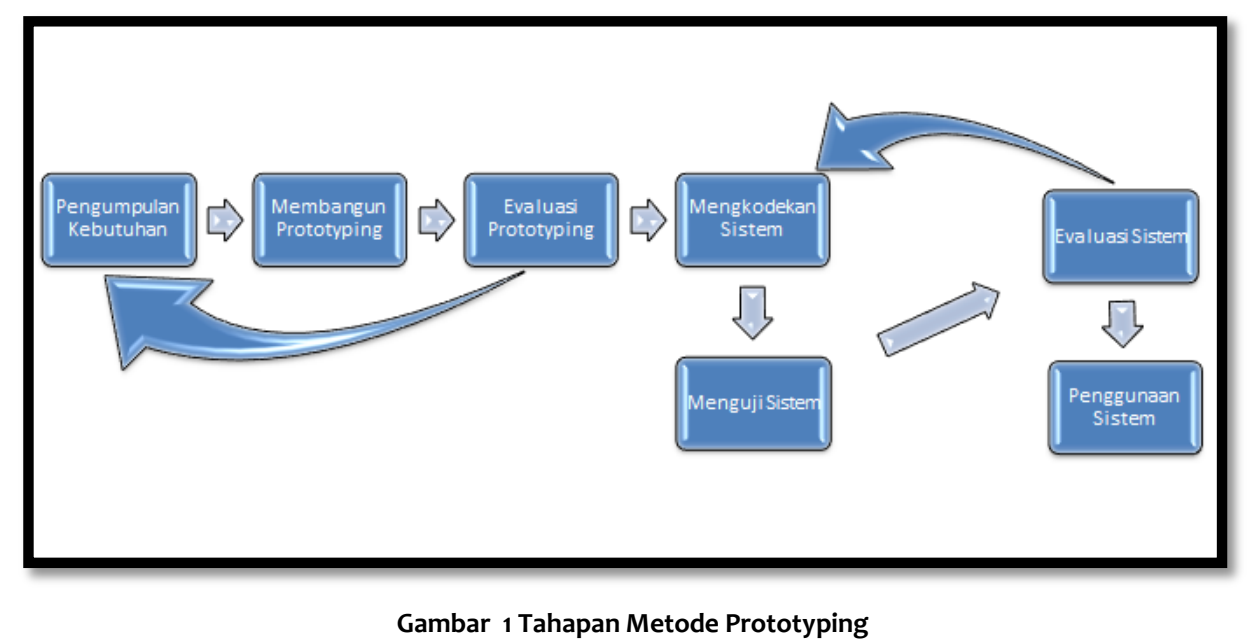

1. Pengumpulan Kebutuhan

Pada tahap pengumpulan kebutuhan, user dan pengembang bersama-sama mendefinisikan format software, mengidentifikasikan kebutuhan, dan sistem yang dibuat.

2. Membangun Prototype / Prototyping

Membangun prototyping dengan membuat perancangan sementara yang berfokus pada penyajian kepada user.

3. Evaluasi Prototyping 
Pada tahap ini user melakukan evaluasi tentang prototyping yang dibangun, sudah sesuai dengan keinginan dan kebutuhan user atau belum. Jika tidak sesuai, prototyping akan direvisi dengan mengulangi langkah-langkah sebelumnya.

4. Mengodekan Sistem

Di tahap ini, prototyping yang sudah disepakati kemudian diterjemahkan ke dalam bahasa pemrograman yang sesuai.

5. Menguji Sistem

Setelah sistem sudah menjadi software yang siap pakai, software akan di tes dahulu sebelum digunakan.

6. Evaluasi Sistem

Di tahap ini, user akan mengevaluasi sistem yang sudah dibuat, sudah sesuai dengan yang diinginkan atau belum. Jika tidak sesuai, pengembang akan mengulangi langkah ke-4 dan 5 .

7. Menggunakan Sistem

Software yang telah diuji dan diterima klien siap digunakan.

\section{Hasil dan Pembahasan}

Program pengabdian kepada masyarakat berlangsung mulai bulan Juli 2019 hingga September 2020. Secara umum, semua kegiatan yang sudah direncanakan telah terlaksana dengan baik. Kegiatan pengabdian kepada masyarakat dimulai dengan diskusi bersama pengurus inti Badko Bantul terkait permsalahan yang ada. Setelah proses diskusi selesai, dihasilkan analisis masalah pada Badko Bantul. Kelemahan dari segi pelayanan dapat dilihat dari proses pencarian lambat karena data-data yang diperlukan masih dalam bentuk arsip-arsip sehingga kualitas pelayanan kurang memuaskan. Seringkali tempat penyimpanan arsip tidak hanya di satu orang, tetapi beberapa orang sehingga menambah lama waktu pencarian. Untuk mengatasi kelemahan tersebut dilakukan peningkatan pelayanan laporan, baik untuk intern Badko maupun instansi terkait, seperti Kementrian Agama Kabupaten Bantul. Peningkatan pelayanan ini berkenaan dengan penggunaan sistem baru yang mendukung sistem kinerja. Hal ini dilakukan agar kinerja dapat ditingkatkan sebagaimana mestinya. Informasi yang bisa disediakan dari sistem yang baru ini terdiri atas laporan data unit, laporan data akreditasi unit, laporan data ustaz, laporan data santri, dan laporan data ketersediaan ustaz dalam satu unit TPA. Halaman utama dari sistem informasi yang dibuat ditunjukkan pada gambar 2 :

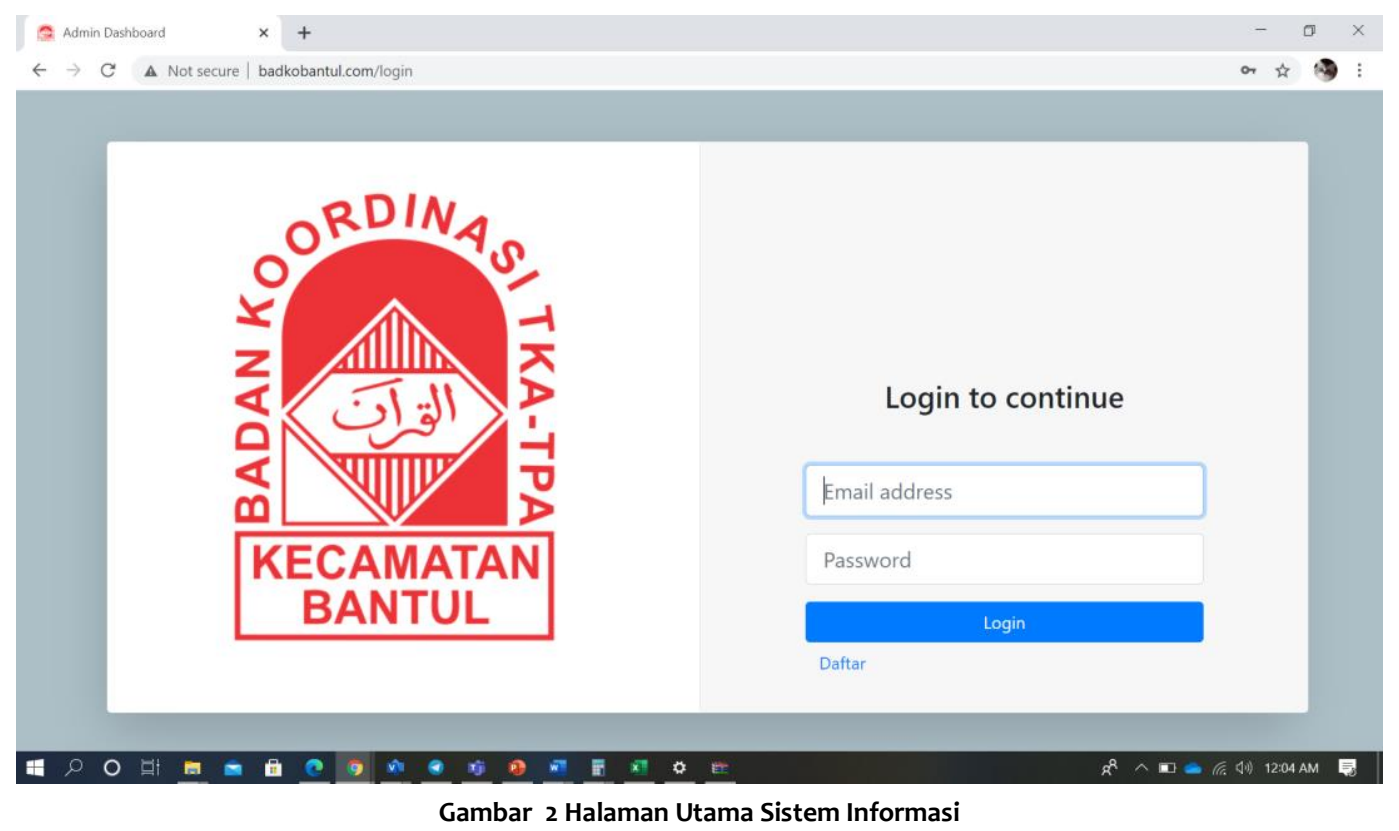


Pada gambar 2, setiap TKA dan TPA diwajibkan untuk mendaftarkan satu orang perwakilan ustaz atau ustazahnya untuk menjadi admin. Dalam hal ini, pihak Badko Bantul bertindak sebagai super admin. Setelah calon admin sekolah mendaftar dan telah di verifikasi oleh super admin, admin sekolah wajib mengisikan data tentang TKA atau TPA-nya. Untuk proses login, admin sekolah dapat melakukan login dengan cara memasukkan alamat email dan password. Halaman laporan data unit dapat dilihat pada gambar 3 :

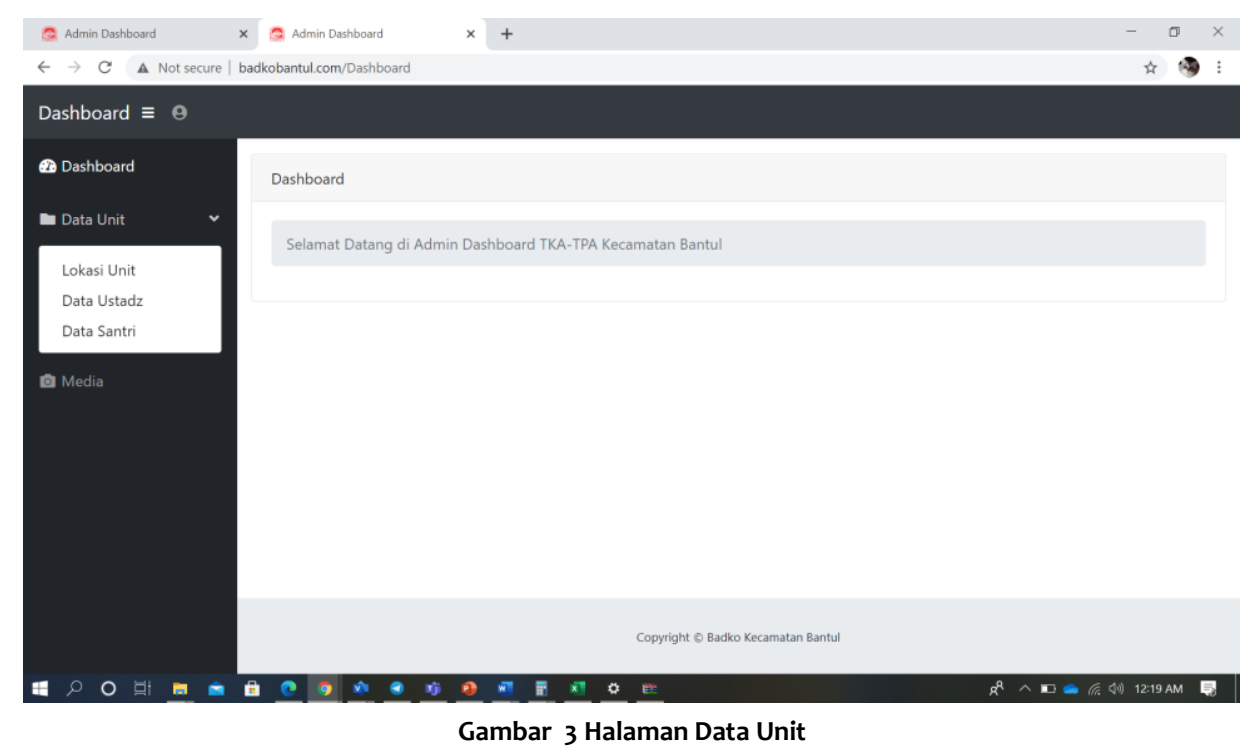

Laporan data unit terbagi menjadi tiga bagian, yaitu lokasi unit, data ustaz dan data santri. Pada bagian lokasi unit, terdapat beberapa hal yang harus diisi oleh pihak TKA atau TPA, seperti terlihat pada gambar 4 . 


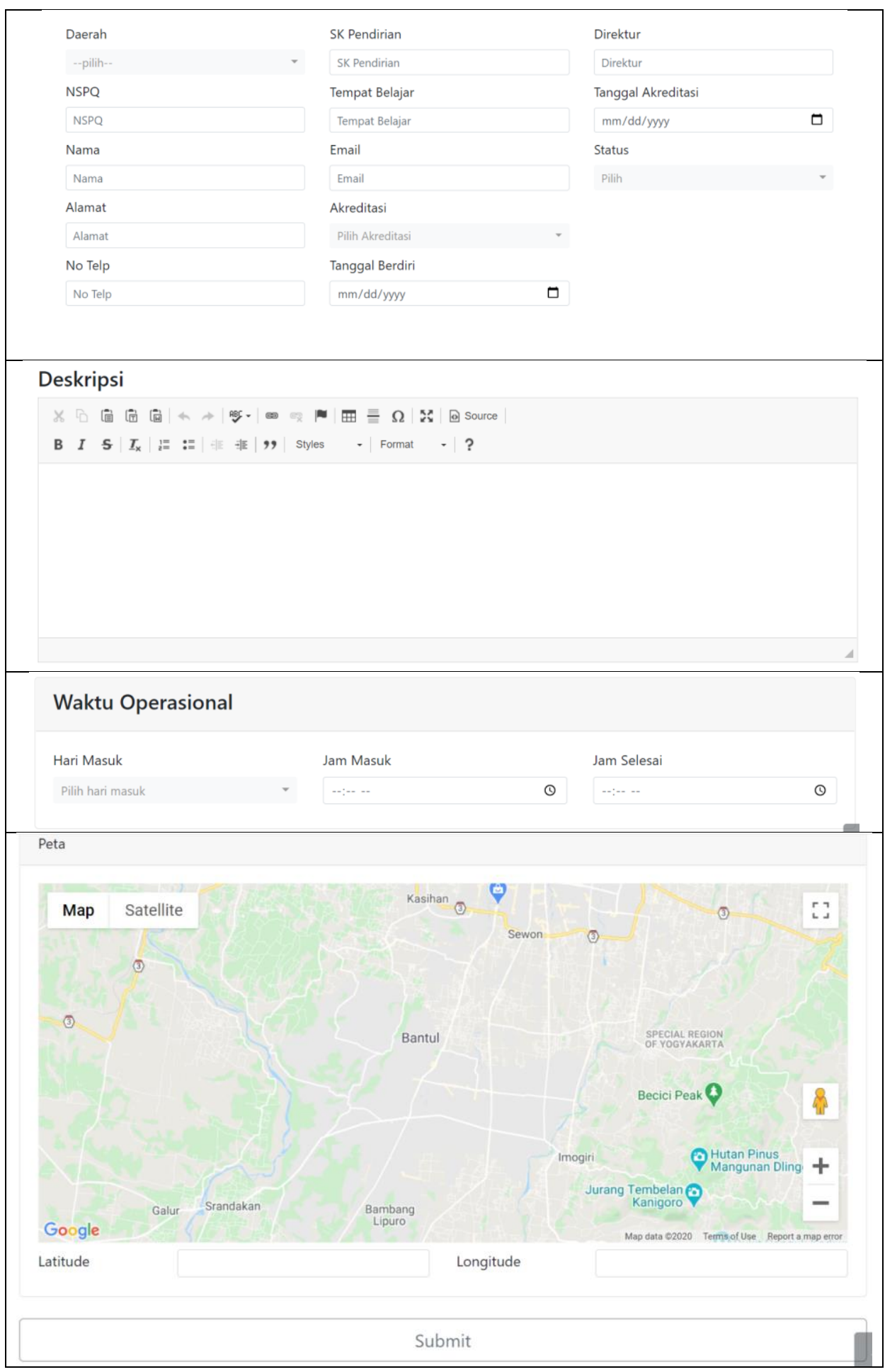

Gambar 4 Halaman Data Unit

Hal pertama yang harus di-input oleh pihak admin sekolah adalah data terkait unit itu sendiri, termasuk di dalamnya data akreditasi unit dan data lokasi unit, yakni peta dari unit itu sendiri. Pada bagian deskripsi, pihak sekolah harus mengisi cerita singkat tentang penjabaran sekola nya. Paga bagian peta, pihak sekolah harus mengisikan koordinat lokasi sekolahnya. Selanjutnya, halaman data ustadz dapat diperlihatkan pada gambar 5. 


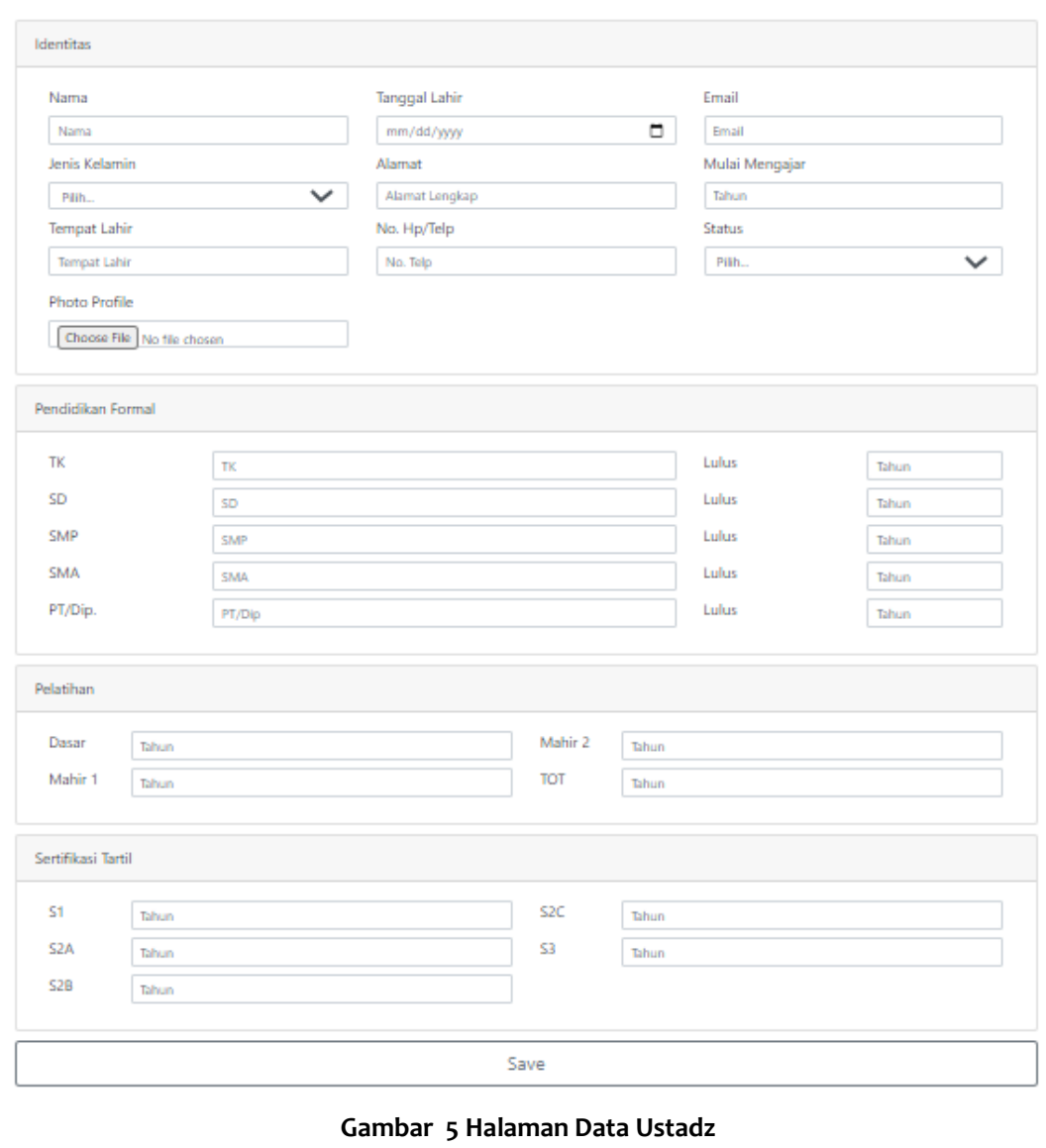

Pada halaman data ustaz, setiap ustaz dan ustazah wajib mengisikan data terkait dengan riwayat pendidikannya. Selanjutnya adalah data santri. Pengisian data santri dapat dilihat pada gambar 6 berikut.

\begin{tabular}{|l|l|l|}
\hline File Santri & & \\
\hline Unggah File & Unduh Format & \\
\hline Show 10 entries & Nama File & No data available in table \\
\hline No & Nama File & Action \\
\hline No & & \\
\hline
\end{tabular}

Gambar 6 Halaman Data Santri

Pada halaman input data santri, setiap admin dapat mengunggah data santrinya dengan cara mengunduh terlebih dahulu format data santri yang ada pada sistem. Setelah sistem informasi selesai dibuat pada tanggal 21 Oktober 2020, lalu dilakukan serah terima sistem informasi kepada pihak Badko Bantul. Kegiatan ini dapat dilihat pada gambar 7. 


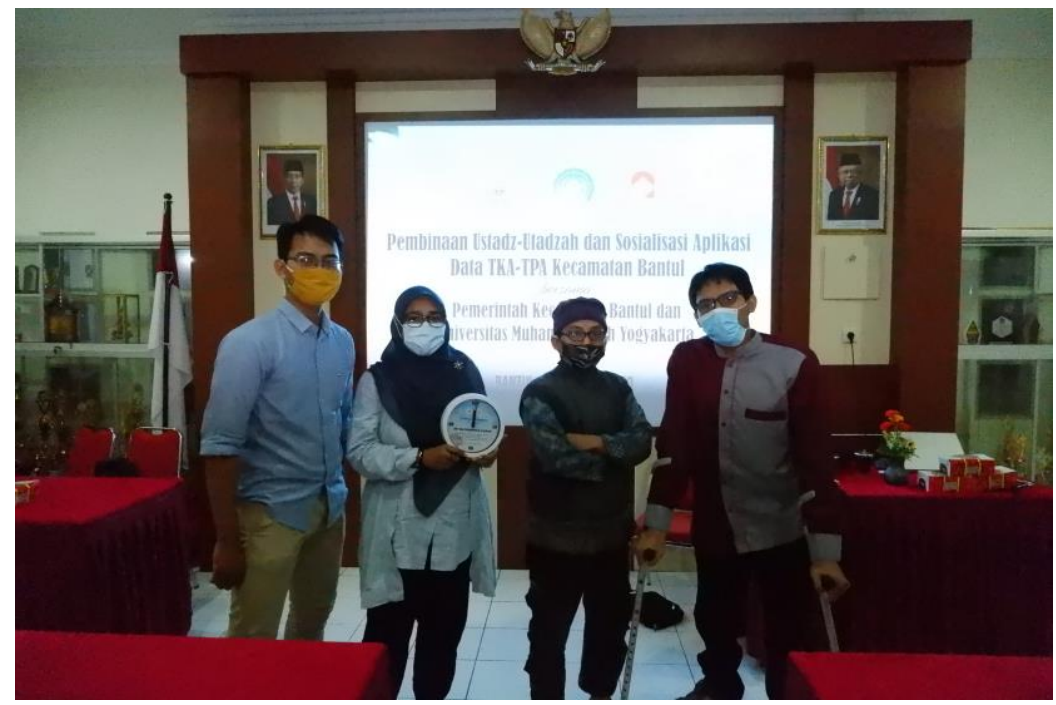

Gambar 7 Serah Terima Dengan Pihak BADKO

Acara serah terima berlangsung di kantor Kecamatan Bantul yang dihadiri oleh Bapak Camat Bantul beserta ketua dari Badko Bantul itu sendiri.

\section{Simpulan}

Pembuatan sistem informasi untuk pengabdian kepada masyarakat sudah berjalan dengan baik dan memasuki tahap implementasi. Pihak Badko Bantul telah menunjukkan dukungan dan partisipasinya, di samping dukungan dari pihak TKA dan TPA Bantul. Pemerintah desa juga telah menunjukkan dukungan dan kesiapan untuk menerapkan sistem informasi yang telah dibuat. Pihak Badko sendiri menginginkan adanya kerja sama lanjutan dengan pihak UMY.

\section{Ucapan Terima Kasih}

Tim pengabdian memberikan apresiasi dan ucapan terima kasih kepada Universitas Muhammadiyah Yogyakarta melalui Lembaga Penelitian, Publikasi dan Pengabdian Masyarakat (LP3M) Divisi Pengabdian dan Pelayanan Masyarakat yang telah mendukung sepenuhnya kegiatan ini. Selanjutnya,tim juga mengucapkan terima kasih kepada pihak Badko Bantul sebagai mitra pengabdian atas kepercayaan dan izin yang diberikan untuk mengabdi.

\section{Daftar Pustaka}

IMK10-Desain_User_Interface.pdf. (2020, 11 13). Retrieved from repository.dinus.ac.id: https://repository.dinus.ac.id/docs/ajar/IMK10-Desain_User_Interface.pdf

Jejaring. (2008, Februari 23). https://www.jejaring.web.id/pengertian-geo-tagging/. Retrieved from www.jejaring.web.id.

Munawar. (2005). Pemodelan Visual dengan UML. Yogyakarta: Graha Ilmu. 